\title{
Primary empty sella: cause of visual failure or chance association?
}

At some point in their career most ophthalmologists will face the problem of a patient with unexplained visual loss and an empty sella turcica on neuro-imaging. Should the visual loss be ascribed to empty sella syndrome, or should the empty sella be considered a coincidental finding and other pathology sought?

There have been many case reports and a few reviews ${ }^{1-26}$ discussing empty sella and its possible role in the pathogenesis of visual loss. However, most of these date from the era of pneumoencephalography or CT scanning and the spectrum of patients is probably different from that seen today with the advent of magnetic resonance imaging (MRI) of the anterior visual pathway.

The appearance of empty sella on neuroimaging is due to partial or total loss of pituitary tissue, enlargement of the sella turcica or both. A primary or idiopathic empty sella (PES) is thought to be due to an incompetent diaphragm sellae, which has been shown to be present in $10 \%$ of an autopsy series. ${ }^{2}$ The defect in the diaphragm allows arachnoid to herniate through the opening compressing the pituitary gland and eroding the floor of the sella. This is consistent with the reported association between PES and pseudotumour cerebri. ${ }^{7,17}$ The defect in the diaphragm may allow the increased intracranial pressure to force an arachnoid diverticulum through the preexisting defect compressing the pituitary and eroding the sella floor. In this setting PES may be reversible if intracranial pressure is normalised. ${ }^{27}$ Secondary empty sella most commonly occurs following spontaneous or post-treatment regression of pituitary tumours and is more likely to be associated with visual field defects than PES. ${ }^{9,16}$

PES is a common incidental finding, though estimates of prevalence vary according to the definition of empty sella and the detection method. Busch ${ }^{1}$ found that the pituitary gland was confined to a small remnant on the floor of the sella turcica in $5.5 \%$ of autopsy cases. In another autopsy series Bergland et al. ${ }^{2}$ found that $23 \%$ of cases had more than a $2 \mathrm{~mm}$ gap between the pituitary gland and the diaphragm. The advent of MRI may allow more accurate determination of prevalence but only if there is widespread agreement on the definition of empty sella. One study of 500 consecutive patients undergoing MRI showed an overall prevalence of partially empty sellae of $28 \%$, with a progressive increase in prevalence with age and a higher prevalence in women. ${ }^{28}$

Given the reported prevalence of up to $28 \%$ empty sella would be expected to be present in a significant proportion of patients with visual field defects without implying any pathogenetic role. When there is no other obvious explanation for the visual field loss, for example binasal field defects ${ }^{14,15,25}$ or low tension glaucoma, ${ }^{18,19}$ PES is more likely to be regarded as being significant.

An association between PES and glaucomatous optic atrophy has been made by some authors ${ }^{18,19}$ who felt that concurrence of empty sella and disc cupping was not due to chance alone. Other workers have reached the opposite conclusion. Rouhiainen and Terasvirta ${ }^{20} \mathrm{CT}$ scanned 15 patients with low tension glaucoma and found one empty sella which they felt was a chance association. Beattie and Trope ${ }^{22}$ saw 8 patients with primary empty sella in their glaucoma practice and felt that visual failure was attributable to open angle glaucoma rather than the empty sella in all but one case.

Almost every type of visual field defect has been described in association with PES. In addition to the arcuate scotomas and binasal defects described above, bilateral blindspot enlargement, ${ }^{15}$ homonymous achromatopsia, ${ }^{6}$ central scotoma ${ }^{22}$ and unilateral temporal defects ${ }^{6}$ have also been described.

The prevalence of field defects in patients with primary empty sella is not known. One small study of 31 cases of PES did not disclose any fields defects attributable to empty sella. ${ }^{5}$

Two mechanisms have been invoked to account for visual failure in primary empty sella: prolapse of the suprasellar visual system (SVS) into the empty sella and ischaemia due to stretching of perforating vessels which arise from the infundibular stalk. ${ }^{2}$ Kaufman et al. ${ }^{21}$ reviewed the MRI scans of 24 patients with PES and found that the normal straight line relationship of the intracranial optic nerve, optic chiasm and optic tract was altered in 3 patients. The patient with the least marked angulation of
P.G. Griffiths

M. Dayan

A. Coulthard Royal Victoria Infirmary Newcastle upon Tyne, UK Mr Philip G. Griffiths, FRCS, FRCOphth Eye Department Claremont Wing Royal Victoria Infirmary Queen Victoria Road Newcastle upon Tyne NE1 4LZ, UK

Tel: $+44(0) 1912325131$, ext 25447 
the SVS had a monocular upper temporal depression of the left visual field; another patient with more marked angulation of the SVS had bilateral non-progressive upper temporal field defects that had been present for 28 years. Unfortunately the clinical descriptions of these cases are limited. There are other anecdotal accounts of prolapsed SVS and visual field loss associated with empty sella ${ }^{3,14}$ but clear-cut evidence linking prolapse and stretching of the visual pathway with visual loss in PES is lacking.

At present a pathogenetic role of PES in visual failure is based on guilt by association. Evidence is largely anecdotal and authors reach apparently contradictory conclusions based on the same evidence. Until it can be shown that empty sella is found more commonly in patients with visual failure and that visual field loss is more common in patients with PES the association should be viewed with scepticism. With the advent of high-resolution MRI the time is right for a reappraisal of empty sella syndrome.

\section{References}

1. Busch W. Die Morphologie der Sella Turcica und ihre Beziehungen zur Hypophyse. Arch Pathol Anat 1951;320:437-58.

2. Bergland RN, Bronson SR, Torack RM. Anatomical variation in pituitary gland and adjacent structures in 225 human autopsy cases. J Neurosurg 1968;28:93-9.

3. Motara R, Norrell H. Consequences of a deficient sellar diaphragm. J Neurosurg 1970;32:565-73.

4. Olson DR, Guiot G, Derome P. The symptomatic empty sella: prevention and correction via the transsphenoidal approach. J Neurosurg 1972;37:533-7.

5. Neelon FA, Goree JA, Lebovitz HE. The primary empty sella: clinical and radiographic characteristics and endocrine function. Medicine 1973;52:73-92.

6. Berke JP, Buxton LF, Kokmen E. The 'empty' sella. Neurology 1975;25:1137-43.

7. Foley KM, Posner JB. Does pseudotumour cerebri cause the empty sella syndrome? Neurology 1975;25:565-9.

8. Buckman MT, Husain M, Carlow TJ, Peake GT. Primary empty sella syndrome with visual field defects. Am J Med 1976;61:124-8.

9. Jordan RM, Kendall JW, Kerber CW. The primary empty sella syndrome. Am J Med 1977;62:569-80.

10. Nakajyo S, Kiso A, Fujino $H$, et al. Visual impairment after chiasmopexy for primary empty sella syndrome with descent of the 3rd ventricle. Jpn Rev Clin Ophthalmol 1978;5:39-42.
11. Cupps TR, Woolf PD. Primary empty sella syndrome with panhypopituitarism, diabetes insipidus and visual field defects. Acta Endocrinol 1978;89:445-60.

12. Okamato S, Matsuzaki H, Kitihara H, Irie J, Wakamatsu K, Funahashi T. Two cases of primary empty sella. Jpn Rev Clin Ophthalmol 1980;6:58-62.

13. Shinoda Y, Nakayoshi N, Matsuao M. Empty sella syndromes with visual field disturbance. Folia Jpn Ophthalmol 1982;33:1811-5.

14. Gocho M, Mishima H, Choshi K, et al. Three cases of primary empty sella syndrome with bilateral nasal hemianopsia. Jpn Clin Ophthalmol 1982;36:957-62.

15. Shinoda Y, Ohnishi $Y$, Abe M, et al. Empty sella syndrome with visual field disturbance. Jpn J Ophthalmol 1983;27:24854 .

16. McFadzean RM. The empty sella syndrome: a review of 14 cases. Trans Ophthalmol Soc UK 1983;103:537-42.

17. Pollock SC, Bromber BS. Visual loss in a patient with primary empty sella. Arch Ophthalmol 1987;105:1487-9.

18. Neetons A, Smet H. Low tension glaucoma: a presenting sign of empty sella syndrome. Neuro-ophthalmology 1987;7:123-31.

19. Yamabayashi S, Tesuya $Y$, Takaya S, Shigeon T. A case of 'low tension glaucoma' with primary empty sella. Br J Ophthalmol 1988;1972:852-5.

20. Rouhiainen $\mathrm{H}$, Terasvirta M. Co-existence of empty sella syndrome and low tension glaucoma. Acta Ophthalmol (Copenh) 1989;67:367-70.

21. Kaufman B, Tomsak RL, Kaufman B, et al. Herniation of the suprasellar visual system and third ventricle into empty sellae. AJR 1989;152:597-607.

22. Beattie AM, Trope GE. Glaucomatous optic neuropathy and field loss in primary empty sella syndrome. Can J Ophthalmol 1991;26:377-82.

23. Braatvedt GD, Corrall RJ. The empty sella syndrome: much ado about nothing. Br J Hosp Med 1992;47:523-5.

24. Cennamo G, Rosa N, De Palma L, Pastena B. Echographic and ophthalmodynamometric study in empty sella syndrome. Ophthalmologica 1993;206:29-32.

25. Charteris DG, Cullen JF. Binasal field defects in primary empty sella syndrome. J Neuro-ophthalmol 1996;16:110-4.

26. Au Eong KG, Hariharan S, Chua EC, Leong S, Wong MC, Tseng PSF. Idiopathic intracranial hypertension, empty sella turcica and polycystic ovary syndrome: a case report. Singapore Med J 1997;38:129-30.

27. Zagardo MT, Cail WS, Kelman ST, Rothman MI. Reversible empty sella in idiopathic intracranial hypertension: an indicator of successful therapy? Am J Neuroradiol 1996;17:1953-6.

28. Foresti M, Guidali A, Susanna P. Primary empty sella: incidence in 500 asymptomatic subjects examined with magnetic resonance. Radiol Med 1991;81:803-7. 